\title{
MORPHOLOGY OF POLY(TETRAOXANE) PREPARED BY RADIATION-INDUCED POLYMERIZATION IN THE SOLID STATE
}

\author{
By Hiroshi Mitomo*1, Yuhei Watanabe ${ }^{* 2}$ and Isamu Kuriyama*3 \\ *1 (College of Technology, Gunma University, Kiryu, Gunma 376, Japan) \\ * 2 (Japan Atomic Energy Research Institute, Takasaki Radiation Chemistry \\ Research Establishment, Takasaki, Gunma 370-12, Japan) \\ * 3 (Irradiation Development Association, Takasaki, Gunma 370-12. Japan)
}

\begin{abstract}
Morphology and crystal orientation of poly (tetraoxane) ( $\mathrm{PT}_{\mathrm{E}} \mathrm{OX}$ ) prepared by $\gamma$-ray induced polymeriza tion of tetraoxane $\left(\mathrm{T}_{\mathrm{E}} \mathrm{OX}\right)$ single crystal were studied. The two-step postpolymerization process was applied and the polymer yield was high. The polymer yield is rather low at the first step postpolymerization, but it significantly increased at the second step because of the presence of $\mathrm{PT}_{\mathrm{E}} \mathrm{OX}$ formed at the first step. The role of the resulting polymer can be considered to act as spatial guide or a substrate for epitaxial growth when the polymer chain grows. The extended chain crystal is always formed by this polymerization method and the lamellar crystal is formed at postpolymerization temperature above $80^{\circ} \mathrm{C}$, while the suberystal is formed below $90^{\circ} \mathrm{C}$. Though all samples show net-like texture, most of the molecular chains orients along the fiber axis, impling that these polymers are composed of the so-called "shish kebab" structure.
\end{abstract}

\section{INTRODUCTION}

It has been found that poly (tetraoxane) ( $\left.\mathrm{PT}_{\mathrm{E}} \mathrm{OX}\right)$ obtained by $\gamma$-ray induced polymerization in single crystal of $\mathrm{T}_{\mathrm{E}} \mathrm{OX}$ gives an oriented $\mathrm{PT}_{\mathrm{E}} \mathrm{OX}$ crystal $^{1,2)}$. It has been suggested ${ }^{3)}$ that $\mathrm{PT}_{\mathrm{E}} \mathrm{OX}$ has the extended chain crystal (main crystal), similar to poly (trioxane) (PTOX), because no diffraction peak is observed by small-angle X-ray scattering (SAXS) method. Nakase et $\mathrm{al}^{4)}$ reported that a weak spot-like scattering corresponding to ca. $100 \AA$ is observed for $\mathrm{PT}_{\mathrm{E}} \mathrm{OX}$ postpolymerized at $105^{\circ} \mathrm{C}$, which is caused by lamellar crys tals situated between fibrillar bundles of the extended chain crystals. It has been reported that $\mathrm{PT}_{E} \mathrm{OX}$ is composed of three kind of crystals, depending on the polymerization temperature. Namely, main- and subcrystals are found in the polymer obtained at postpolymerization temperatures below $80^{\circ} \mathrm{C}$, while lamellar crystals in addition to main- and sub-crystals are observed between $80^{\circ} \mathrm{C}$ and $90^{\circ} \mathrm{C}$, however, above $90^{\circ} \mathrm{C}$ the subcrystal cannot be found. The c-axis of the subcrystals orients perpendicular to that of the main crystals. Both sub- and lamellar crystals exist between the fibrils of main crystals ${ }^{5,6}$.

In the present study, we investigated morphology of $\mathrm{PT}_{\mathrm{E}} \mathrm{OX}$ prepared by the two-step process of postpolymerization, and characteristics or merits of this polymerization method. We also selected the conditions of radiation-induced polymerizations in the solid state to obtain the polymer in high yield. The polymer yield, the melting point, and the structural change of $\mathrm{PT}_{\mathrm{E}} \mathrm{OX}$ at the second step postpolymerization were examined. These data were compared with the data of one step polymerization, and the role of the resulting polymer formed at the first step was discussed. Moreover, the morphology of $\mathrm{PT}_{\mathrm{E}} \mathrm{OX}$ crystal was compared with that of $\mathrm{PT}_{\mathrm{E}} \mathrm{OX}$ obtained by iodine-initiated polymerization in the solid state in the presence of a small quantity of solvent (benzene). 


\section{EXPERIMENTAL}

Tetraoxane single crystals (ca. $1 \mathrm{~mm} \phi \times 10 \mathrm{~mm}$ ) were prepared by sublimation under reduced pressure. These crystals were packed into glass amples in portions of about $1 \mathrm{~g}$ under an air atmosphere. The amples were sealed and irradiated with ${ }^{60} \mathrm{Co}-\gamma$-rays at room temperature for $1 \mathrm{hr}$ (the radiation dose rate was $10 \mathrm{kGy} / \mathrm{hr}$ ). These samples were postpolymerized at $105^{\circ} \mathrm{C}$ for $1.5 \mathrm{hr}$ in the amples (sample A1). Both samples A2 and A3 were obtained by applying the second step process; after irradiation at room temperature for $1 \mathrm{hr}$ at the radiation dose rate of $1 \mathrm{kGy} / \mathrm{hr}$, postpolymerization was carried out for $1.5 \mathrm{hr}$ at $80^{\circ} \mathrm{C}$ for $\mathrm{A} 2$ and at $105^{\circ} \mathrm{C}$ for $\mathrm{A} 3$. For comparison, B series of samples obtained under the conditions as shown in Table 1 were used. After the postpolymerization, these crystals were extracted with acetone to remove the unchanged monomer completely and dried in vacuum. The appearance of poly (tetraoxane) was needle-shaped structure and it was almost the same as that of monomeric tetraoxane single crystals. How. ever, colour of the polymer crystal changes into white and cloudy from the transparent colour of $\mathrm{T}_{\mathrm{E}} \mathrm{OX}$ single crystal.

The melting behavior of a $3 \mathrm{mg}$ sample was studied by using a Perkin Elmer differential scanning calorimeter DSC-II at a heating rate of $20^{\circ} \mathrm{C} / \mathrm{min}$ under a nitrogen atmosphere. The temperature scale was calibrated using the melting points of indium $\left(156.4^{\circ} \mathrm{C}\right)$ and benzoic acid $\left(121^{\circ} \mathrm{C}\right)$.

Small-angle $X$-ray scattering (SAXS) patterns were obtained with a JEOL Rotex JRX-12 rotating anode using a pin-hole collimation system $(0.5-0.3 \mathrm{~mm} \phi)$. The axis of needle-shaped polymers was normal to the $X$-ray beam. Wide-angle X-ray scattering (WAXS) was carried out using a cylindrical camera (or a flat plate camera) for rotation patterns. The axis of rotation was the long axis (c-axis) of polymer crystal.

\section{RESULTS AND DISCUSSION}

\subsection{Three Kinds of Crystals of Postpolymerized Samples}

The polymer yields for the three samples of $A$ and $B$ series are shown in Table 1 together with conditions of the two-step process of radiation and postpolymerization. The polymer yields obtained at the first step postpolymerization were $58.6 \%$ (A1) and $24 \%$ (B1). Howev$\mathrm{er}$, the yields were significantly increased by the second step postpolymerization, e.g. $84.5 \%$ for sample $A 3$ and $50.4 \%$ for sample B3. If the B series was postpolymerized at the second step at above $90^{\circ} \mathrm{C}$ for $5 \mathrm{~min}$, the polymer yields increased higher than $90 \%$. Polymerization time at the first step was decided where the increment in the polymer yield almost levelled off. Though the radiation dose at the second step for A series was one tenth of the first step, increments in the polymer yields of $A 2$ and $A 3$ at the second step were 46 and $63 \%$, respectively. Whereas, increments in the polymer yield at the second step were $13 \%$ for sample B2 and $35 \%$ for B3. This implies the polymer yield at the second step ex. ceedingly increased almost irrespectively of an amount of the polymer yield at the first step. At the second step postpolymerization, the resulting polymer formed at the first step may acts as spatial guide or a substrate for

Table 1 Radiation doses and postpolymerization conditions of the samples of $\mathrm{A}$ and $B$ series at two step of irradiation and postpolymerization, and the polymer yields of these samples.

\begin{tabular}{c|cc|cc|c}
\hline \multirow{2}{*}{ Sample No. } & \multicolumn{2}{|c|}{ First step } & \multicolumn{2}{|c|}{ Second step } & \multirow{2}{*}{ Yield (\%). } \\
\cline { 2 - 5 } & $\begin{array}{c}\text { Radiation } \\
\text { dose }\end{array}$ & $\begin{array}{c}\text { Post- } \\
\text { polymerization }\end{array}$ & $\begin{array}{c}\text { Radiation } \\
\text { dose }\end{array}$ & $\begin{array}{c}\text { Post. } \\
\text { polymerization }\end{array}$ & \\
\hline A 1 & $10 \mathrm{kGy}$ & $105^{\circ} \mathrm{C}, 1.5 \mathrm{hr}^{*}$ & - & - & 58.6 \\
A 2 & $10 \mathrm{kGy}$ & $105^{\circ} \mathrm{C}, 1.5 \mathrm{hr}$ & $1 \mathrm{kGy}$ & $80^{\circ} \mathrm{C}, 1.5 \mathrm{hr}$ & 77.4 \\
A 3 & $10 \mathrm{kGy}$ & $105^{\circ} \mathrm{C}, 1.5 \mathrm{hr}$ & $1 \mathrm{kGy}$ & $105^{\circ} \mathrm{C}, 1.5 \mathrm{hr}$ & 84.5 \\
B 1 & $10 \mathrm{kGy}$ & $85^{\circ} \mathrm{C}, 18.5 \mathrm{hr}$ & - & - & 24.0 \\
B 2 & $10 \mathrm{kGy}$ & $85^{\circ} \mathrm{C}, 18.5 \mathrm{hr}$ & $10 \mathrm{kGy}$ & $55^{\circ} \mathrm{C}, 1 \mathrm{hr}$ & 33.5 \\
B 3 & $10 \mathrm{kGy}$ & $85^{\circ} \mathrm{C}, 18.5 \mathrm{hr}$ & $10 \mathrm{kGy}$ & $80^{\circ} \mathrm{C}, 0.25 \mathrm{hr}$ & 50.4 \\
\hline
\end{tabular}

*) The polymer yield almost levelled off at this time. 


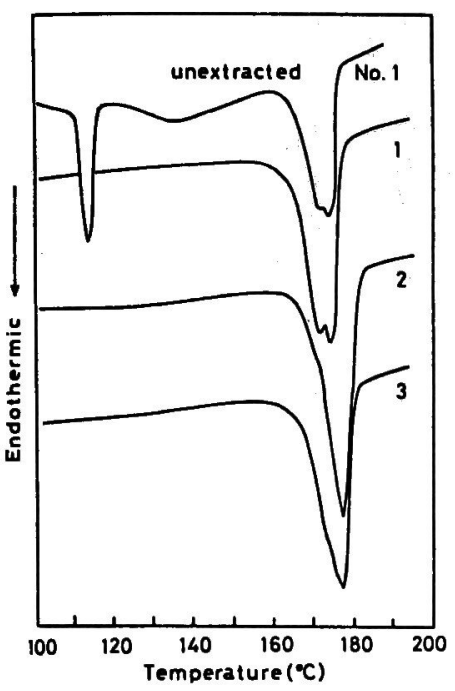

Fig. 1 DSC heating curves of samples $A 1$ (the unextracted and extracted ones), A2 and A3.

epitaxial crystallization when the polymer chain grows, which results in thickening of individual fibrils.

Fig. 1 shows DSC heating curves of the samples. Unextracted sample A1 shows two melting peaks corresponding to melting of monomer $\left(\mathrm{T}_{\mathrm{E}} \mathrm{OX}\right)$ and the polymer $\left(\mathrm{PT}_{\mathrm{E}} \mathrm{OX}\right)$. The peak temperature of $\mathrm{T}_{\mathrm{E}} \mathrm{OX}$ is $114^{\circ} \mathrm{C}$. The melting peak of $\mathrm{PT}_{\mathrm{E}} \mathrm{OX}$ is a doublet appearing at $172^{\circ} \mathrm{C}$ and $175^{\circ} \mathrm{C}$. Extracted sample $\mathrm{A} 1$ shows the same melting peak for $\mathrm{PT}_{\mathrm{E}} \mathrm{OX}$ as unextracted sample $\mathrm{A} 1$ missing the peak for $T_{E} O X$. Extracted samples $A 2$ and $A 3$ show the melting peak for $\mathrm{PT}_{\mathrm{E}} \mathrm{OX}$ at $177^{\circ} \mathrm{C}$ accompanied by a shoulder at a lower temperature $\left(173^{\circ} \mathrm{C}\right)$. In the previous paper ${ }^{7)}$, the melting peak for the samples prepared by the one step postpolymerization became somewhat broader and shifted to lower temperatures as the polymer yield increased. The polymer crystals formed during postpolymerization were introduced somewhat incomplete or distorted portions caused by the difference in unit cell dimensions of both monomer and polymer crystals, which caused the broadening of the melting peaks. On the other hand, the melting peak for the samples postpolymerized by the two-step process shifts to the higher temperature. At the second step of polymerization, the resulting polymer formed at the first step may act as a substrate for epitaxial crystallization when the polymer grows. At the first step, it was formed a vacant slit or space between the extended chain crystal and the monomer crystal due to the difference in unit cell dimensions ${ }^{3)}$. By this reason, the growth and crystallization of the polymer are promoted more completely, resulting in formation of the polymer crystal having the high melting point.

The enthalpies of melting, which were estimated from the peak areas in Fig. 1, are $193 \mathrm{~J} / \mathrm{g}$ (sample A1), 214 $\mathrm{J} / \mathrm{g}$ (sample A2) and $201 \mathrm{~J} / \mathrm{g}$ (sample A3). These values are very close to the melting enthalpies of one step postpolymerization, which were almost constant for any samples ${ }^{8,9)}$, although the melting points shifted to lower temperatures as the polymer yield increased. In fact, the melting peak temperatures of $\mathrm{PT}_{\mathrm{E}} \mathrm{OXs}$ prepared by preirradiation at $1 \mathrm{kGy}$ and $10 \mathrm{kGy}$ followed by the one step postpolymerization at $105^{\circ} \mathrm{C}$ for $1 \mathrm{hr}$ were ca. $184^{\circ} \mathrm{C}$ and $178^{\circ} \mathrm{C}$, respectively. At the higher irradiation dose, much amounts of radicals were formed so that the rate of polymerization increased but the molecular weight of polymer decreased inversely ${ }^{10)}$.

Fig. 2 shows X-ray rotation photographs of samples with the $\mathrm{c}$-axis of prism-like polymer crystal (b-axis of $\mathrm{T}_{\mathrm{E}} \mathrm{OX}$ ) as the rotation axis. Unextracted sample A1 shows two kind of diffractions corresponding to the monomer and polymer. It has been reported that the $c$ axis (fiber axis) of $\mathrm{PT}_{\mathrm{E}} \mathrm{OX}$ is parallel to the b-axis of $\mathrm{T}_{\mathrm{E}} \mathrm{OX}$ and the a-axis of $\mathrm{PT}_{\mathrm{E}} \mathrm{OX}$ coincides to the $\mathrm{c}$-axis of
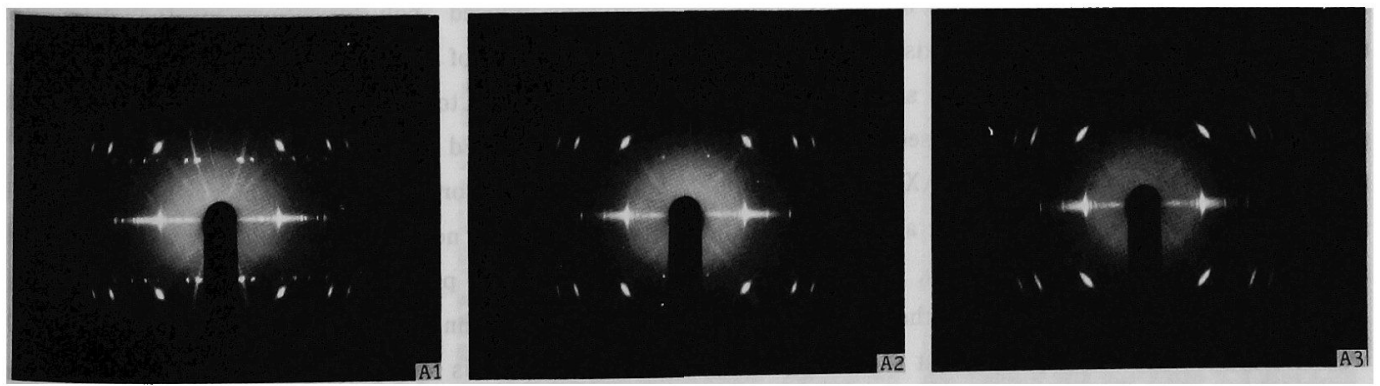

Fig. $2 \mathrm{X}$-ray rotation photographs of the unextracted sample $\mathrm{A} 1$ and the extracted samples $\mathrm{A} 2$ and $\mathrm{A} 3$. The rotation axis is the $b$-axis of the original $T_{E} O X$ single crystal. 

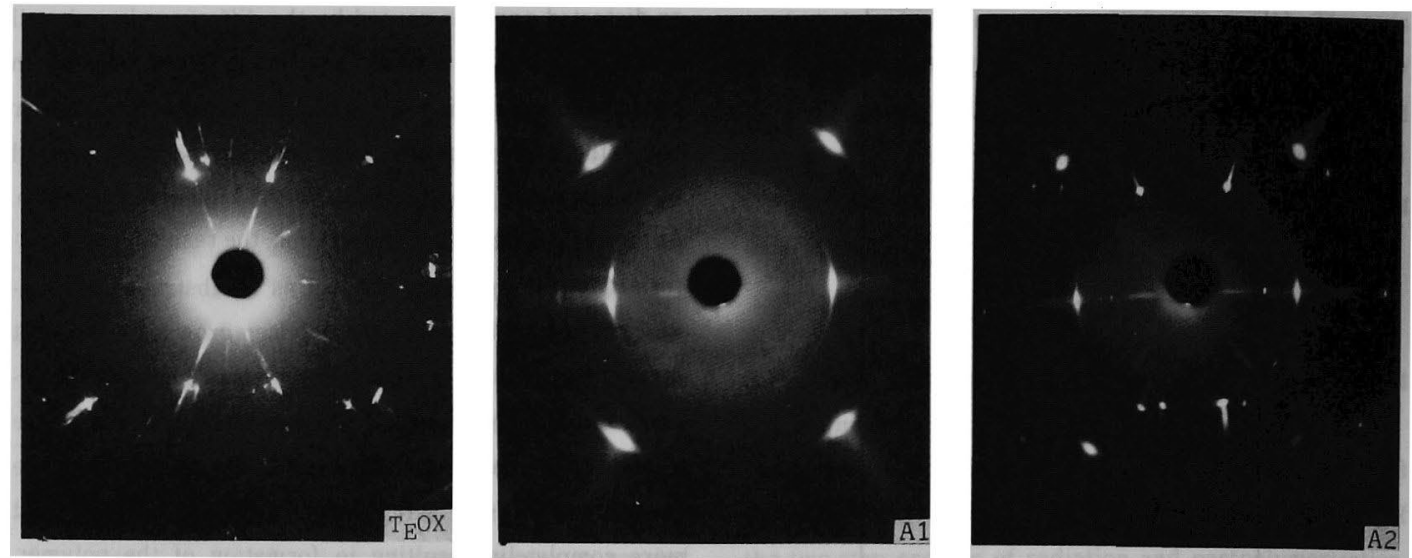

Fig. 3 WAXS patterns of $T_{E} O X$ single crystal and the extracted samples $A 1$ and $A 2$ using a flat plate camera.
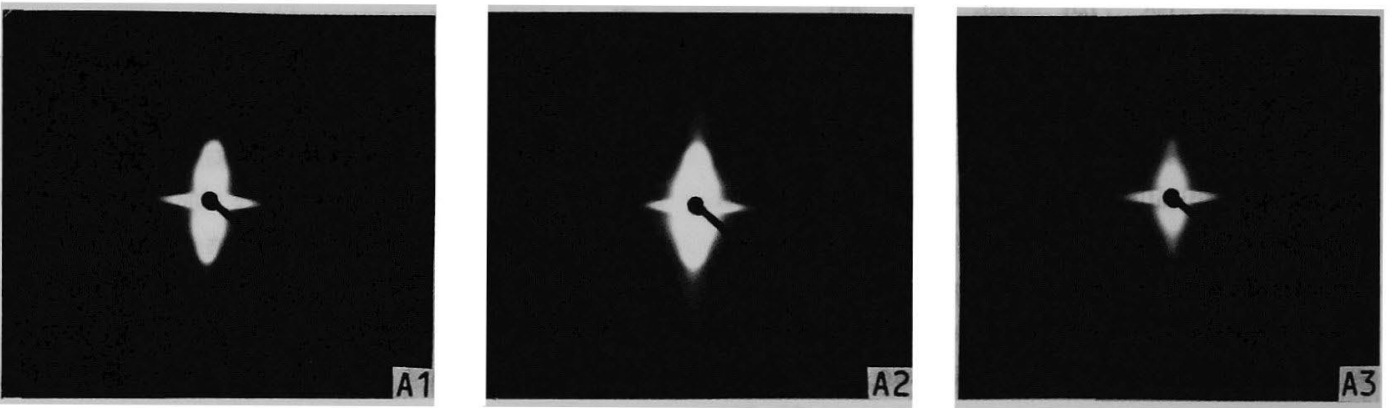

Fig. 4 SAXS photographs of samples A1, A2 and A3.

$\mathrm{T}_{\mathrm{E}} \mathrm{OX}^{3)}$. After extraction with acetone, no diffraction corresponding to the monomer was observed as shown in photographs of samples A2 and A3. The patterns of samples $A 1$ (extracted) and $A 3$ are almost similar, while sample A2 shows the extra diffractions caused by the subcrystal $^{5)}$. We could obtain just the same $x$-ray rotation photographs of $\mathrm{PT}_{\mathrm{E}} \mathrm{OXs}$ as that reported by Chatani et al. ${ }^{3)}$

Fig. 3 shows typical WAXS photographs of $\mathrm{T}_{\mathrm{E}} \mathrm{OX}$, samples $A 1$ and $A 2$ using a flat plate camera for a fixed sample. $\mathrm{T}_{\mathrm{E}} \mathrm{OX}$ shows WAXS pattern of b-axis orientation, while $\mathrm{PT}_{\mathrm{E}} \mathrm{OX}$ shows that of $\mathrm{c}$-axis orientation. The photograph of sample A3 was quite similar to that of sample A1. The extra diffractions caused by the subcrystal are clearly observed in the WAXS photograph of sample A2. Since sample A2 was kept at $80^{\circ} \mathrm{C}$ for $1.5 \mathrm{hr}$ at the second step postpolymerization, the subcrystal of $\mathrm{PT}_{\mathrm{E}} \mathrm{OX}$, which is perpendicular to the main crystal ${ }^{3)}$, was formed. It has been reported that the subcrystal is formed at postpolymerization temperature lower than $90^{\circ} \mathrm{C}^{6)}$.
SAXS photographs of these samples are shown in Fig. 4. Long spacings of the samples are ca. $100 \AA(100$ $\AA$-scattering) estimated from the first and the second order diffractions of them. This indicates the formation of lamellar stacking between fibrils during the first step postpolymerization. It has been reported that $\mathrm{PT}_{\mathrm{E}} \mathrm{OX}$ obtained by radiation-induced polymerization at $100^{\circ} \mathrm{C}$ shows similar lamellar structure having a long spacing of $83 \AA^{5)}$. It has been also reported that the extended chain crystal (main crystal) is formed in $\mathrm{PT}_{\mathrm{E}} \mathrm{OX}$ obtained by radiation-induced polymerization in the solid state (single crystal of monomer), however, the lamellar structure in addition to this main crystal is also formed in the polymer obtained at the temperature higher than $80^{\circ} \mathrm{C}^{6}$. A strong equatorial streak is observed, which reflects the presence of needle-shaped voids between fibrils with high orientation parallel to the fiber axis ${ }^{11)}$, while a very broad diffraction corresponding to ca. $500 \AA$ ( 1500 $\AA$-scattering) is observed perpendicular to the fiber axis. It was reported that the broad spot (500 $\AA$-scattering) appeared more clearly at a lower angle as 

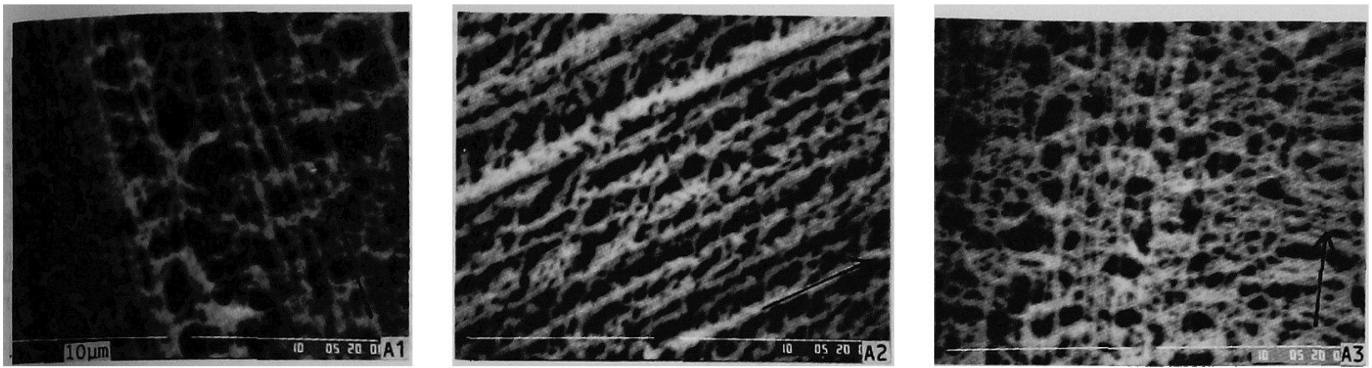

Fig Scanning electron micrographs of samples A1, A2 and A3. The fiber axis of the sample is para llel to the arrow.

the polymer yield increased $^{7)}$. Since the 500 $\AA$-scattering along the meridian and the strong equato. rial streak significantly decreased in SAXS intensity by impregnation of poly (ethylene glycol) or silicone oil, both scatterings are caused by voids more or less oriented perpendicular and parallel to the c-axis of the polymer crystal, respectively.

The periodic appearance of voids along the c-axis is a characteristic of the $\mathrm{PT}_{\mathrm{E}} \mathrm{OX}$ texture arranged periodically on a fibrillar crystal due to the difference in unit cell dimensions of both the crystals of $\mathrm{T}_{\mathrm{E}} \mathrm{OX}$ and $\mathrm{PT}_{\mathrm{E}} \mathrm{OX}$. In the previous paper ${ }^{9)}$, the same periodical formation of voids has been reported, where the presence of the rippled (striped) feature perpendicular to the fiber axis was observed for the as-polymerized $\mathrm{PT}_{\mathrm{E}} \mathrm{OX}$ irradiated with $1 \mathrm{MGy}$. Therefore, they suggested that the fibrillar crystal, or the extended chain crystal, must be composed of the stacking crystallites (and the periodical formation of voids ${ }^{7)}$ ). Whereas, the $100 \AA$-scattering along the meridian hardly decreased in the intensity by the impregnation in the oil, impling the lamellar stacking formation during the postpolymerization.

\subsection{Scanning Electron Micrographs of Post- polymerized Samples}

Fig. 5 shows scanning electron micrographs (SEM) of samples A1, A2 and A3. Fibrils, whose diameter is $100-200 \mathrm{~nm}$, are observed orienting along the fiber axis accompanied by the fibrils almost normal to them. All samples show the same trend of net-like texture and their $X$-ray patterns indicated orienting of molecular chains parallel to the fiber axis. There is no difference in appearance of subcrystal and lamellar crystal in sample A2. Therefore, we can infer that the main fibrils are composed of extended chain crystals, while intersecting fibrils normal to them are mostly composed of folded chain crystals (and a small amount of subcrystals for sample A2) in the similar manner as "shish kebab" type. The similar structure was also observed for these $\mathrm{PT}_{\mathrm{E}} \mathrm{OXs}$ annealed at temperatures just below its melting point or prepared by oriented crystallization ${ }^{5)}$.

Fig. 6 shows SEM photographs of samples of B series. These micrographs are of higher magnification than
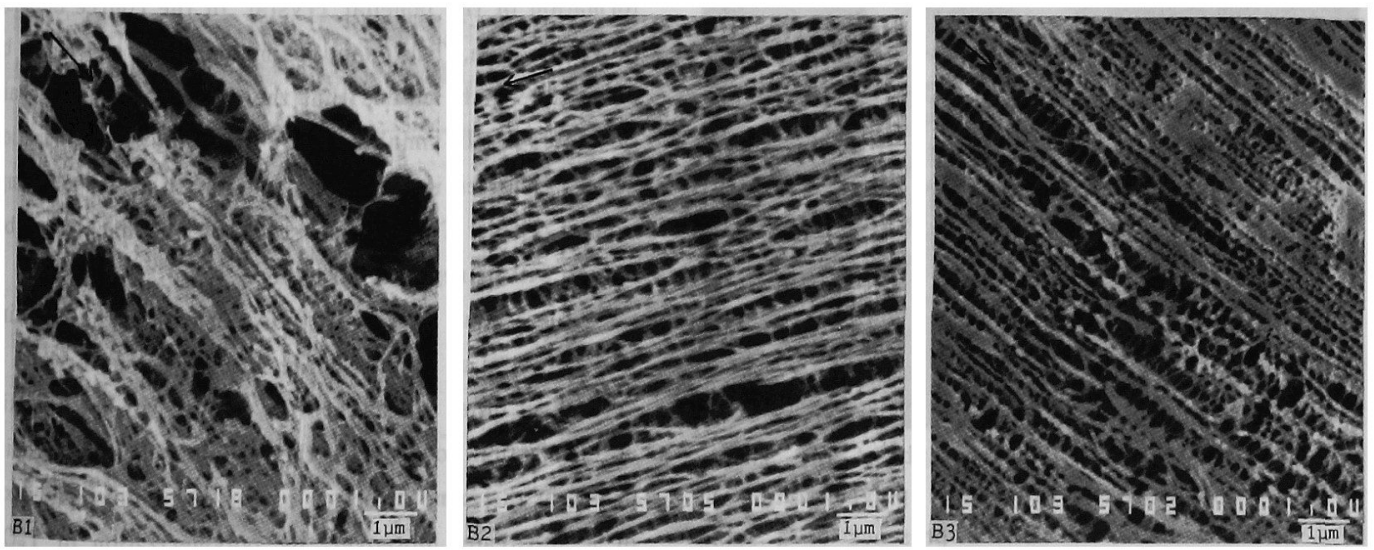

Fig. 6 Scanning electron micrographs of $B$ series of samples (B1, B2 and B3). 
those in Fig. 5, however, the same net-like texture is also observed for every sample. WAXS pattern of sample B1 showed the same pattern as that of sample A2, reflecting the presence of three kinds of crystals, i.e., main-, suband lamellar crystals ${ }^{7)}$. There is no difference in tex tures of these samples, but we dare say that the thickening of individual fibrils or filling up of vacant space between fibrils is observed more clearly as the polymer yield is increased. Similar fibrillar texture of $\mathrm{PT}_{\mathrm{E}} \mathrm{OX}$ obtained by radiation-induced polymerization to that reported by Wegner et al. ${ }^{10)}$ is sometimes observed, but the typically stacking texture of lamellar crystals similar to that observed for PTOX $^{5)}$ was not found for our $\mathrm{PT}_{\mathrm{E}} \mathrm{OX}$ samples.

It was reported that the degradation of the polymer during the polymerization in air causes the destruction of the polymer crystal formed ${ }^{12)}$. Therefore, the molecular weights of $\mathrm{PT}_{\mathrm{E}} \mathrm{OX}$ obtained by the polymerization in air was estimated to be smaller than that obtained by polymerization in vacuum (ca. one fourth-one tenth) ${ }^{13}$. However, there is no difference in the appearance of net like texture.

For comparison, a typical SEM photograph of the sample obtained by iodine-initiated polymerization at $105^{\circ} \mathrm{C}$ for $4 \mathrm{hr}$ in air in the presence of a small amount of solvent is shown in Fig. 7. The concentrations of iodine and solvent (benzene) were $30 \mathrm{ppm}$ and $0.5 \%$, respectively. The polymer yield was ca. $37 \%$ by this method. The long spacing of this sample was ca. $100 \AA$ and the melting point was $173^{\circ} \mathrm{C}$ (corresponds to the melting peak at a

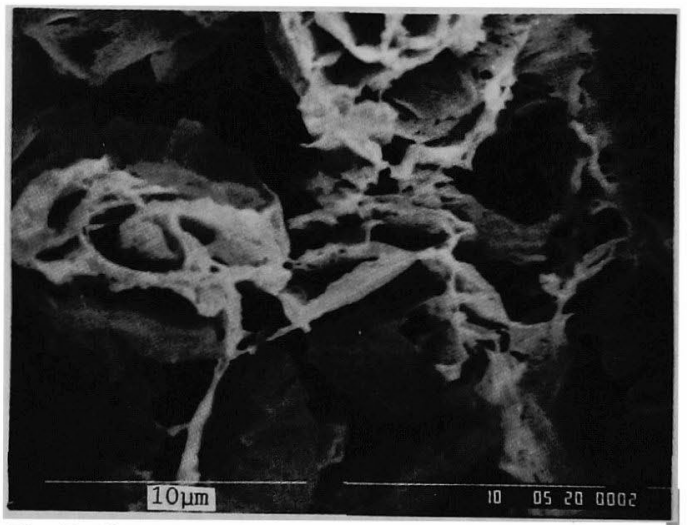

Fig. 7 Scanning electron micrograph of the sample obtained by iodine-initiated polymerization at $105^{\circ} \mathrm{C}$ for $4 \mathrm{hr}$ in the presence of a small amount of benzene. lower temperature of sample A3). This implies that the resulting polymer is composed of lamellar crystals. By this process, it is considered that benzene is squeezed out from resulting polymers and concentrated at the boundary of growing polymer chains. This can be considered that the polymerization occurs in the solution rather than in the solid state. Therefore, the fibrillar orientation of $\mathrm{T}_{\mathrm{E}} \mathrm{OX}$ single crystal is lost and the petallike texture is observed instead of the net-like texture.

The distance of monomeric units along the helical axis of $\mathrm{PT}_{\mathrm{E}} \mathrm{OX}$ is $1.93 \AA$, whereas in $\mathrm{T}_{\mathrm{E}} \mathrm{OX}$ there are four monomeric units (crown-shaped structure) along the $b$ axis in the periodic distance of $4.18 \AA$, i.e., $1.05 \AA$ per one monomeric unit ${ }^{3)}$. Explanation of the increment of polymer yield at higher temperature is that the rate of polymerization becomes large enough compared with the radical life. The chain mobility is considered to be another factor. In order to prolong this solid state polymerization along the $b$-axis of $\mathrm{T}_{\mathrm{E}} \mathrm{OX}$, polymer chains must be mobile enough to be dilatable along this direction and shrinkable laterally (i.e., the area of a-c plane of monomer crystal is $132 \AA^{2}$, which shrinks to $103 \AA^{2}$ corresponding to that of a-b plane of polymer crystal $\left.^{3}\right)$. The higher mobility of molecules is caused at the higher polymerization temperature which results in the high po lymer yield. At the low polymerization temperature, two kinds of crystals, i.e., the main and subcrystals are formed as a result of low mobility of molecule. By the steric hindrance, the growing polymer chain tends to turn toward a right angle, which results in formation of the subcrystal. Polymer chains have high mobility at the higher temperature (above $80^{\circ} \mathrm{C}$ ), which results in formation of the lamellar crystal. In the cource of postpolymerization, TOX (and formaldehyde) gas could be detected, which implies that the growing polymer chain backbites itself simultaneously with the polymerization so as to shorten itself to the same length as the consump tion of $\mathrm{T}_{\mathrm{E}} \mathrm{OX}$. The precise study on the backbiting behavior will be reported elsewhere ${ }^{14)}$.

At the second step of postpolymerization, the resulting polymer acts as spatial guide and a nucleus or core of crystal, in other words, acts as a substrate for epitaxial crystallization, on which the growing polymer chains orient in the same direction as the crystallographic axes of a substrate. Moreover, by polymerization of $\mathrm{T}_{\mathrm{E}} \mathrm{OX}$, vacant slits or spaces are formed between the polymer 
crystal and the monomer crystal parallel to the polymer chain due to the difference in unit cell dimensions ${ }^{3}$, which causes less steric hindrance for the growing polywer chain. From these reasons, the polymer yield significantly increased at the second step of postpolymerization.

\section{REFERENCES}

1) S. Okamura, K. Hayashi, and Y. Kitanishi, J. Polym. Sci. 58, 925 (1962).

2) K. Hayashi, H. Ochi, M. Nishii, Y. Miyake, and S. Okamura, J. Polym. Sci., B1. 427 (1963).

3) Y. Chatani, T. Uchida, H. Tadokoro, K. Hayashi, M. Nishii and S. Okamura, J. Macromol. Sci., Phys., B2(4), 567 (1968).

4) T. Kato, Y. Nakase, O. Yoda, I. Kuriyama, and A. Odajima. Polym. J., 8, 331 (1976).

5) T. Amano, E. W. Fischer and G. Hinrichsen, J. Macro- mol. Sci., Phys., B3, 209 (1969)

6) A. Odajima, T. Ishibashi, Y. Nakase, and I. Kuriyama, J. Mater. Sci., 12, 1443 (1977).

7) Y. Nakase, T. Kato, O. Yoda, 1. Kuriyama and A. Odajima, Polym. J., 9, 605 (1977).

8) Y. Nakase, M. Yoshida, A. Ito and K. Hayashi, J. Polym. Sci., A-1 9, 465 (1971).

9) Y. Nakase, I. Kuriyama, and A. Odajima, Adv. Polym. Sci., 65, 81 (1984).

10) A. Munoz-Escalona and G. Wegner, Makromol. Chem., 148, 331 (1971).

11) W. O. Statton, J. Polym. Sci., 58, 205 (1962).

12) M. Sakamoto, I. Ishigaki, M. Kumakura, H. Yamashina, I. Iwai, A. Ito, and K. Hayashi, J. Macromol. Chem., 1, 639 (1966).

13) Y. Nakase and I. Kuriyama, Polym. J.. 4, 517 (1973).

14) Y. Watanabe, H. Mitomo and I. Kuriyama (to be published).

放射線固相重合によって得られたポリテトラオキサンのモルフォロジー

\begin{tabular}{|c|c|c|}
\hline & 群馬大学工業短期大学部 & 三友宏志 \\
\hline & 日本原子力研究所 高崎研究所 & 渡辺祐平 \\
\hline & 放射線照射振興協会 & 栗山 将 \\
\hline テトラオキサン $\left(\mathrm{T}_{\mathrm{E}} \mathrm{OX}\right)$ 単結晶の $\gamma$ 線照射重合によっ & \multicolumn{2}{|c|}{ はエピタキシャル生長における基盤の役割を果すものと } \\
\hline 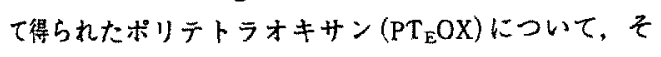 & \multicolumn{2}{|c|}{ 考えられる。この重合方式によってのびきり型結晶が常 } \\
\hline モルフォロジーや結晶配向がしらべられた。二段階後 & \multicolumn{2}{|c|}{ に形成される。また折りたた結晶は $80^{\circ} \mathrm{C}$ 以上の重合 } \\
\hline 重合法加適用され，これによって高いポリマー収率を得 & \multicolumn{2}{|c|}{ 温度において形成され，一方副結晶は $90^{\circ} \mathrm{C}$ 以下の温度 } \\
\hline ることができた。第一段の後重合では，固体のテトラオ & \multicolumn{2}{|c|}{ で形成される。すべての陚料において網目状構造がみら } \\
\hline サンからのポリマー収率はかなり低いが、第二段階で & \multicolumn{2}{|c|}{ れるが，ほとんどの分子鎖は峨維軸の方向に並んでお } \\
\hline 假階で生成した $\mathrm{PT}_{\mathrm{E}} \mathrm{OX}$ の存在によってそれは著し & \multicolumn{2}{|c|}{$\begin{array}{l}\text { ク，いわゅる“シシカバブ”構造をとっていると考えら } \\
\text { れる。 }\end{array}$} \\
\hline
\end{tabular}

生長しつつある高分子鎖を空間的に誘導したり，あるい 